\title{
Jesus and Spirituality: Reading the Fourth Gospel in the Light of the Indian Culture
}

\author{
Johnson Thomaskutty ${ }^{1,2}$ (D) \\ 1 Department of New Testament, The United Theological College, Bengaluru, Karnataka 560046, India; \\ jesusandjohnson@gmail.com \\ 2 Department of New Testament and Related Literature, Faculty of Theology and Religion, \\ University of Pretoria, Pretoria 0002, South Africa
}

Citation: Thomaskutty, Johnson. 2021. Jesus and Spirituality: Reading the Fourth Gospel in the Light of the Indian Culture. Religions 12: 780. https://doi.org/10.3390/rel12090780

Academic Editors: Paul N. Anderson and Joel B. Green

Received: 4 August 2021

Accepted: 11 September 2021

Published: 17 September 2021

Publisher's Note: MDPI stays neutral with regard to jurisdictional claims in published maps and institutional affiliations.

Copyright: (C) 2021 by the author. Licensee MDPI, Basel, Switzerland. This article is an open access article distributed under the terms and conditions of the Creative Commons Attribution (CC BY) license (https:/ / creativecommons.org/licenses/by/ $4.0 /)$.

\begin{abstract}
The Gospel of John is considered as one of the significant literary masterpieces that appeals to Indian spirituality and ideals in multifarious ways. The Gospel has unique features as a universalistic rhetoric that encompasses feelings and aspirations of Indians. The character of Jesus in the Gospel and His assimilative power to contemporary realities reverberate the situational aspects of Indian communities. In the current article, first of all, an attempt is made to explore the character of Jesus and the impression of the Johannine spirituality in relation to Indian realities. We also attempt to place the Fourth Gospel in Indian context in order to derive an interpretative dynamism that takes into account both the Jesus of John and the diverse religious and cultural aspects of today's context. The character of Jesus and the spirituality reflected in John have much in common with the mystical traditions of the Indian religions.
\end{abstract}

Keywords: spirituality; fourth gospel; Indian culture; Indian interpretation

\section{Introduction}

The Gospel of John is considered one of the significant writings in the NT that appeals to Indian spirituality and Asian ideals in multifarious ways (Thomaskutty 2021a, pp. 127-56). The Gospel has unique features as a universalistic literary masterpiece that encompasses the feelings and the aspirations of the Indian communities from a universal perspective (Chandrankunnel 2021, pp. 171-92). The Gospel's genre dynamism, features of setting, ideological constructs, character traits, plot structure, and point of view reflect and reveal its assimilative power to reverberate the situational aspects of the Indian religious and contextual realities (Chatman 1978). The protagonist Jesus and the narrator together develop a spirituality of inclusiveness that accommodates the contextual demands beyond the aspects of time and space (Van der Watt 2007a, pp. 9-25; Tovey 2007, pp. 41-73). The cross-cultural nature of the Gospel is demonstrated through the Judean, Galilean and Samaritan integration, and the Jerusalem-centric Sitz im Leben Jesu and the Ephesus-centric Sitz im Leben Kirche intertwining (Guthrie 1990, pp. 272-73; cf. Martyn 1979; Brown 1979). This aspect of the Fourth Gospel can be considered a paradigm in the multi-religious, multi-cultural, and pluralistic context of India (Thomaskutty 2021b, pp. 155-70). In the current article, first of all, an attempt is made to explore the impression of the Johannine spirituality in cross-cultural Indian realities. We also attempt to place the inclusive spirituality of Jesus in the Indian context in order to derive an interpretative dynamism that takes into account the diverse religious and cultural aspects. The spirituality of Jesus reflected in John's Gospel shall be viewed in relation to the mystical traditions of the Indian religions.

The current article outlines some of the important aspects related to Johannine and Indian spiritualities. Some of the significant themes of the Fourth Gospel are analyzed to see their semantic and ideological connections with the contemporary realities. They include: the Word in relation to Sat/Cit, Avatara, and Adisabda, Johannine soteriological aspects in relation to Jnana, Karma, and Bhakti margas, discipleship and its reverberations, 
signs and their symbolical presentation, "I AM" sayings and their functional dynamics, representative characters and their dramatic significance, mystical aspects in John and their resemblances in India, dualistic narratorial features, and others (Thomaskutty 2020, pp. 127-56).

\section{Johannine Themes in the Indian Context}

In his 1820 work entitled The Precepts of Jesus, Raja Ram Mohan Roy, one of the Hindu Renaissance leaders of India, placed the four gospels alongside the Upanishads (Roy 2008). He revered the extracts of Jesus' teaching in the Fourth Gospel with great aptitude alongside the Sermon on the Mount (Matt 5-7; Boyd 2000, pp. 19-20). For Sadhu Sundar Singh, the Bible was the primary standard or pramāna, but he had a preference for John's Gospel as he says "St. John seems to me to have loved Christ more than the other Apostles" (Boyd 2000, p. 96; cf. Appasamy 1958). As a strong proponent of Indianization of the Gospel, Sundar Singh's interpretation of the scripture is based on the metaphor of "water of life in an Indian cup" (see Boyd 2000, pp. 86-109). Furthermore, A. J. Appasamy understood "Christianity as Bhakti Marga" based on the devotional traditions of the Fourth Gospel and the philosophical roots of Ramanuja (Basker 2016, pp. 30-33; cf. Boyd 2000, pp. 110-143; Appasamy 1928). The spiritual truths of the Fourth Gospel and the inclusive spirituality of Jesus are accommodative to the socio-religious aspirations reflected in the Indian context. The following discussion shall give us further details concerning the possible interpretative avenues of the Fourth Gospel in the Indian contextual realities.

\section{The Word as the Sat/Cit, the Avatāra, and the Adisabda}

The Fourth Gospel begins with a well-known rhythm as follows: "In the beginning was the Word, and the Word was with God, and the Word was God" (1:1; Thompson 2001, pp. 1-10). There are parallels between the Fourth Gospel and the Chandogya Upanishad of Hinduism. ${ }^{1}$ In the Chandogya Upanishad, the sage begins his teaching with the words, "In the beginning, Being (sat) alone existed, one without a second" (6.2.1; Kanagaraj 2005, p. 35). In that sense, Jesus as the Word was fully God. The Word becoming flesh and dwelling among humanity is one of the incarnational aspects of the Fourth Gospel (1:14; Moloney [1989] 1998, pp. 38-39, 45). While Jesus is portrayed as the incarnation of God in the Gospel, a similar concept, such as Avatära, is used in Hinduism. The word avatāra comes from the root meaning "to descend," and Rama and Krishna are considered as avatārs of Vishnu (see Gita 4.7.8). ${ }^{2}$ The accommodative spirituality of Jesus as one who descends and saves is the hallmark of the Johannine Christology.

There are some similarities between the Johannine Logos and the Hindu concept of $\mathrm{Om} / \mathrm{Aum}$. The divine sound $\mathrm{Om}$ is derived out of three sounds $\mathrm{A}, \mathrm{U}, \mathrm{M}$, that represent three Vedas of Hinduism and the trimurti of Brahman ("a"), Vishnu (" $\mathrm{u}$ "), and Shiva (" $\mathrm{m}$ "). In the Upanishads, $O m$ is considered as the primordial sound (i.e., Adisabda) and a symbol of true existence (Kanagaraj 2005, pp. 39-41). It is considered as the totality of the manifested world (i.e., ekaksara; "the one syllable" or "the imperishable one"), a droning utterance (i.e., pranava), symbolism of a sacred syllable, and a prayer or mantra of all other mantras (Owens 2008, p. 573). This understanding of Hinduism goes well with the pre-incarnate (1:1-5) and incarnate (1:14) forms of Jesus in John's Gospel. Jesus as the pre-incarnate Word and the incarnate "Word became flesh" demonstrates how God the Father and God the Spirit are integrally connected and revealed through the Son (Moloney [1989] 1998, pp. 34-37, 42-45). The incarnational spirituality of the Fourth Gospel is universal in boundary and eternal in scope (Ringe 1999, pp. 46-61). Thus, the Johannine and the Indian traditions foreground the spiritual and religious resonances undercurrent in the textual horizon.

Keshub Chandra Sen considered God (i.e., Brahman) as Sat, Cit, and Ananda (means "being," "intelligence," and "bliss"). For Sen, in the words of Boyd: "The Logos, then, who in eternity lay as it were asleep in God, is the Word of Creation, Cit (intelligence, wisdom), ever at work in the development of the created world, and in the fullness of time being born as man in Jesus of Nazareth" (Boyd 2000, p. 28). Similarly, Brahmabandhav 
Upādhyāya (1861-1907) considered the Hindu concept of Saccidānanda Brahman on par with the Christian Trinity (see Boyd 2000, pp. 63-74). In his Sanskrit hymn—the Hymn of the Incarnation-Upādhyāya describes Christ as the God-Man and the Logos. Boyd puts it as follows: "Christ is the Image of God (Brahman) and in him the eternal Word (intelligence, Cit), the fullness of the Godhead, dwells. In the refrain, victory (jai) or glory is ascribed to him who is the true Nara-Hari ("Man-God")" (Boyd 2000, p. 78; cf. Anderson 2013). Jesus the Logos can resonate with the Sat as he is one with the Brahman, Cit as he is the divine wisdom from above, the Avatāra as he came to establish righteousness and justice in the world, and the Adisabda as he is God's eternal voice in the universe. Thus, Johannine spirituality can be understood in closer attachment with the Indian ideological aspects and the contextual realities.

\section{John and the Jnana, Karma, and Bhakti Margas}

The Bhagavad Gita describes three paths to salvation: first, the Jnana Marga (a path that emphasizes thoughts and introspection; see Rambachan 2005, p. 7); second, the Karma Marga (a path of ritual action or duties); third, the Bhakti Marga (a path of devotion). ${ }^{3}$ John has exclusive claims such as "I am the Way and the Truth and the Life" (14:6); but the scope of John's soteriology aligns well with the Jnana, Karma, and Bhakti traditions of Hinduism. In John's Gospel, "knowing" (ginōskein) and "believing" (pisteuein) occur together and in several passages they function in relation to other cognates (see 4:53; 6:69; 10:38; 17:8; Gaffney 1965, pp. 215-41). When Jesus says that "My Father is always at his work to this very day, and I, too, am working" (5:17), the aspect of karma can be identified (also see $4: 34-38 ; 9: 3-5 ; 13: 14) .{ }^{4}$ As the Father is engaged in works, the Son is working; as Jesus engages himself in works, the disciples are encouraged to do what he does (13:14; Moloney [1989] 1998, pp. 375-76).

Alongside "knowing" and "working," the aspect of devoting oneself in discipleship $(1: 43 ; 21: 19,22)$, worship (4:21-24; 9:38), and belief $(1: 7 ; 3: 15-17 ; 4: 39-42 ; 6: 29-34 ; 7: 38-39$; $11: 25-28 ; 16: 27-30)$ is also demonstrated. Jnana Marga leads people to attain knowledge over ignorance and to understand the truths of ultimate reality (Basker 2016, p. 36). While Karma Marga engages people to do selfless works in the society, Bhakti Marga helps people focus on God. ${ }^{5}$ Jesus performed an action as a hypodeigma (i.e., an "example") for the disciples to follow (13:1-20). Thus, John emphasizes the "knowing," "working," and "devoting" aspects of Christian living in a dynamic way (Thomaskutty 2019, pp. 75-96). It emphasizes the riddle of Johannine spirituality as it is, on the one hand, exclusive, and on the other hand, inclusive (Anderson 2014, pp. 144-45). This phenomenon of Johannine spirituality is both accommodative and disruptive at the same time.

\section{Johannine Discipleship and Indian Realities}

The call of the first disciples (1:19-51) provides us with a brief understanding of the Johannine discipleship. John the Baptist introduces Jesus to the world: "Behold, the Lamb of God" (1:36; cf. 1:29). His witness about Jesus resulted into two of his disciples following Jesus. Here we see the first record of people following Jesus (1:37). The verb "follow" serves as a metaphor for discipleship throughout the Fourth Gospel (cf. 1:37, 43; 8:12; 10:4-5, 15, 27; 12:26; 21:19, 22; Thomaskutty 2016, pp. 5-21). ${ }^{6}$ Nicodemus and the woman at the well bring to the foreground two models of discipleship, one of them being a member of the Jewish religious elite (3:1-21) and the other a woman living in a Samaritan village (4:1-26; Lee 1994, pp. 36-94). Andrew (1:35-42; 6:8; 12:22; Bennema 2009, pp. 47-52), Philip (1:43-44; 6:8; 12:22; Bennema 2009, pp. 47-52), Peter (1:40-42; 6:66-70; 13:6-10; 18:15-26; 20:1-10; 21:1-23; Bennema 2009, pp. 53-63), the man born blind (9:1-41; Bennema 2009, pp. 136-44), Thomas (11:16; 14:5; 20:24-28; 21:2; Thomaskutty 2018), the family of Mary and Martha (including Lazarus; 11:1-54; 12:1-8; Brant 2011, pp. 175-76), the Beloved Disciple (13:23; 19:26-27; 20:2; 21:7, 20), Mary Magdalene (19:25; 20:1-18; Brant 2011, pp. 266-70), and others follow Jesus (Wilkins 1992, pp. 176-82). The disciples are those who believe, 
follow, and worship Jesus. The entire Gospel is placed in an inclusio of Jesus' commands to follow him in 1:43 and in 21:19/22 (Moloney [1989] 1998, pp. 55-57, 557-58).

The Guru-Shishya tradition of India is old, and takes us back to the Upanishadic period (Kohli 1993, p. 18). Just as Jesus was a walking teacher and the disciples followed him in a Peripatetic style, ${ }^{7}$ the Asian religious teachers such as Dronacharya, Buddha, Mahavira, and the Sikh Gurus imparted knowledge to the disciples while they walked together. Guru Dronacharya was a legendary and illustrious teacher in the Drona Parva of the Mahabharata (see Vyasa 2013; Basker 2016, p. 78). He taught royal princes of both the clans, Pandavas and Kauravas. The Guru-Shishya relationship was emphasized in the Sikh religion. The Punjabi word sikh ("learner") is related to the Sanskrit shishya ("disciple"). After a succession of ten gurus beginning from Guru Nanak, the Guru Granth Sahib became the final Guru. ${ }^{8}$ Similarly, Mahavira and Buddha had large number of followers. Both in the Johannine and in the Indian religious traditions, following the master is considered as one of the significant aspects of spirituality.

\section{The Signs and Their Significance in India}

The signs recorded in the Fourth Gospel function in a dynamic way as they contribute semantically to its narrative framework. Jesus turns water into wine at a wedding in order to solve a family's pressing problem in an honor and shame socio-cultural context, and to launch his public ministry (2:1-11; Beasley-Murray 1999, pp. 32-37; Coloe 2013, p. 205). By healing an official's son, he encourages the official to progress in his journey of faith (4:46-54; Barrett 1978, pp. 205-8). By feeding the five thousand, he demonstrates his compassion for all of humanity (6:1-15), and by walking on the water, he reveals his power and authority over all of nature (6:16-21; Beasley-Murray 1999, pp. 85-96). In healing a man born blind, he shows the reader how such a sign can nurture a person's faith development (9:1-41; Barrett 1978, pp. 292-304), and by restoring Lazarus to life, he gives the reader a sense of his concern for all who belong to the community of God (11:1-44; Thomaskutty 2017b, pp. 67-68). Finally, by enabling a miraculous catch of fish, he reveals his Lordship to the disciples (21:6-11). ${ }^{9}$ The above mentioned situations are echoed in the Indian context where divine signs are significant (Anderson 2014, pp. 145-46). ${ }^{10}$

In the words of Blackburn, the Synoptic dynameis ("deeds of power") and the Johannine sēmeia ("signs") function in different ways. While the Synoptic evangelists present pistis on the part of the suppliants (or their representatives) as a prerequisite for receiving miraculous help (Mark 2:5; 6:5-6), in John, the signs ideally result in pistis (Blackburn 1992, p. 550). As John's Jesus is open-ended and unconditional in performing miraculous signs, the multi-cultural and pluralistic Indian communities can embrace him wholeheartedly. The Indian context is known for the large numbers of sick and the poor, who seek a healer and a provider such as Jesus. While Jesus engages in the mission of God, he uses the signs as a means of revealing his glory and to build a holistic community (Thomaskutty 2017b, pp. 67-68). In a context of social isolation, quarantine, global shut down, and death and bereavement due to the pandemics such as Covid-19, the Johannine Jesus can be introduced as a paradigmatic healer to the Indian communities (Thomaskutty 2021c, pp. 1-11). Thus, Johannine Christ-centered and faith-focused spirituality functions well in the Indian context.

\section{The "I AM" Sayings of Jesus in the Indian Context}

In his ministry, Jesus of John's Gospel grounds his public discourses in equally public actions (Burge 1992, pp. 354-56; cf. Anderson 2011a, pp. 139-206). ${ }^{11}$ His actions and speech develop simultaneously within the Johannine narrative framework. One who feeds five thousand people with physical bread (6:1-15) declares himself to be bread from heaven (6:22-59; Van der Watt 2007b, pp. 186-204). The feast of Tabernacles is actualized by the presence of Jesus as "the light of the world" (8:12; Ball 1996, p. 155). One who gives physical sight to the blind (9:1-7) is introduced, again, as "the light of the world" (9:5; Ball 1996, pp. 80-93). When the sheep are sent out of the synagogue (9:34), Jesus is ready to 
receive them as "the door of the sheep" (10:7; Thomaskutty 2015, pp. 341-45). The leaders of the synagogue are mere hirelings (10:12-13), but Jesus shows himself to be "the good shepherd" $(10: 11,14,16)$ by resolving the struggles of the man born blind (Thomaskutty 2015 , pp. 310-40). One who raises the dead (11:38-44) is himself "the resurrection and the life" (11:25; Lee 1994, pp. 188-224). One who is "the way, the truth, and the life" (14:6) prepares a way and a place in heaven for those who follow him (14:2-3; Ball 1996, pp. 119-28). One who provides the best wine (2:1-11) is himself "the true vine" (15:1-11; Ball 1996, pp. 60-145). Thus, Jesus' utterances are backed up by his actions (see Anderson 2014, pp. 150-52; Tovey 2007, p. 75).

In the Indian context, people highly value those who walk their talk. In religion, politics, and culture such people are given heroic images in society. Politicians who make promises but remain unable to fulfil them are not considered as respectable figures. Indian figures such as Mahatma Gandhi, ${ }^{12}$ Pandita Ramabhai, ${ }^{13}$ and Mother Teresa ${ }^{14}$ are known not only for their rhetoric but also for their actions for community development. In this context, the Johannine Jesus can be identified as an ideal model for human transformation in the pluralistic context of India (Basker 2016, pp. 75-77). Johannine spirituality is wider and inclusive of both the rhetoric and the actions.

\section{Johannine Characters in the Indian Context}

Within the narrative framework, John's characterization is extremely effective. The various characters are memorably presented with the help of a wide range of literary devices and narrative techniques (Thomaskutty 2016, p. 17). One who reads the Johannine story paradigmatically may identify its characters from his/her own context. For example, an Indian or a Nepali reader may identify Nicodemus with a higher-caste Hindu or a Buddhist who seeks to understand Jesus (Blomberg 2001, pp. 91-95). When a reader ministers in a village, addressing the lower-caste women of the region, s/he may identify them with the Samaritan woman (Moloney [1989] 1998, pp. 113-50; Gench 2004, pp. 109-35). "Secret" Christians, those who believe in Jesus but do not take the public step of identifying with the Christian community, seem much such as Joseph of Arimathea (19:38-42). The blind man, the family of Mary and Martha, Mary Magdalene, Thomas, Nathanael, Peter, Philip, and other characters bear a strong resemblance to people we come across on a daily basis. ${ }^{15}$ These are the peculiar narrative dynamics of John's storytelling (Thomaskutty 2016, p. 18). In our own reading, we find the Johannine characters to be quite Indian.

The story of Nathanael (1:43-51) resembles very much the story of Buddha, and the story of the Samaritan woman (4:1-26) resembles in many ways various Buddhist traditions. Similarly, the invalid at the pool of Bethesda (5:1-18) and the man born blind who was healed in Jerusalem (9:1-41) are like the poor beggars in and around the temples, mosques, pagodas, gurudwaras, and other religious centers in the South Asian context (cf. Lee 1994, pp. 161-82). Nathanael as a person who sits under the fig tree (1:48b) and is enlightened to recognize Jesus as the "Son of God" and the "King of Israel" (1:49) resembles in many ways Buddha, who sat under the Bodhi tree in Bodh Gaya and was enlightened (Blomberg 2001, p. 83). ${ }^{16}$

Jesus who comes to the Samaritan village and asks a woman for water corresponds in many ways to Ananda, a famous disciple of Buddha, who asked a Matanga Caste woman for water at a well (see Chacko 2019, p. 3). The social distancing between communities is seen in her question, "How do you ask water of me, an outcaste who may not touch thee without contamination?" (cf. John 4:9; Narasu 2009, p. 84). Ananda replied: "My sister, I ask not of thee thy caste, I ask for water to drink" (cf. John 4:10, 13-14). He breaks the socio-cultural and religious barriers in drinking the water. ${ }^{17}$ The "othering" by social distancing is transcended and this daring action crossed the binary spaces of me and you, to a third space, where both could engage in their conversation and interaction (Chacko 2019, p. 3; Thomaskutty 2017a, pp. 64-68). Ananda thanked her and showered on her a blessing from Buddha and went away. This girl, attracted by the defiant action of the Buddhist Bhikshu, followed his footprints and reached the Buddhist Sangha Viharam (Ashram; 
Chacko 2019, p. 3; Thomaskutty 2017a, pp. 64-68). Encounters near wells are common in Indian village contexts, as women are expected to fetch water for the whole day from the village well. The local and the universal are interwoven throughout this Gospel. This peculiar feature of the Gospel makes it both a local and a universal rhetoric (Thomaskutty 2020, pp. 3-14).

\section{Mysticism in John and in the Indian Religions}

The spirituality reflected in John's Gospel has much in common with the mystical traditions of the Indian religions. The following aspects can be considered significant in that regard: first, at the heart of Johannine theology we witness a union between God/Jesus and human beings (6:56; 15:1-17; McPolin 2020, pp. 26-27); second, Jesus' vertical and horizontal relationships are reflected through his mystical expressions such as "All that is mine is yours; all that is yours is mine" (17:10; also see 17:21-23; cf. 14:7-12; McPolin 2020, pp. 27-30); third, as a Gospel of belief and love, the aspects such as believing in and loving God are emphasized to sustain the union between God and believers (3:16; 6:47; Chapters 14-16) ${ }^{18}$ fourth, the language John uses such as "'having fellowship' (koinonia) with the Father and the Son," "to be born of God" or to be "children of God" (1:13), and "I know mine and mine know me" (10:14; 17:3) reveal the integral value of relationships (McPolin 2020, pp. 31-32); fifth, the "knowing," "seeing," and "believing" aspects of the Gospel make it more contemplative, as it demands a deeper level of reflection on the meaning of Christ for our lives (McPolin 2020, pp. 32-33); sixth, the imageries such as "light" (1:9; 8:12; 9:5), "vine and the branches" (15:1-15), and others express the intimacy of communion with Christ forcefully (McPolin 2020, pp. 33-34); seventh, the binding communion between the Father, the Son, the Holy Spirit, and the believer and the inseparable unity is emphasized through the formula of immanence (Schnackenburg 1982; Ashton [1991] 1993, p. 54; McPolin 2020, pp. 34-35). These aspects of the Fourth Gospel resonate in several ways in the Indian thought-world.

The Johannine idea of oneness with God resonates with the Indian religious and philosophical traditions. While Hinduism expresses the view of "Atman is Brahman" ("the soul is one with God"), ${ }^{19}$ Mahayana Buddhism has the idea of tathätā which can be described as "thisness of reality." ${ }^{20}$ Sankara, one of the Indian classical proponents of Advaita (non-dualism) philosophy, see an eternal union between Brahma the Absolute and the Atman or pure consciousness (chaitanyam; Dalal [2010] 2014, p. 6). The Advaita interpretation of Sankara was later on modified by Ramanuja through his Vishishtadvaita (qualified non-dualism) interpretation of Vedanta. ${ }^{21}$ Ramanuja was critical of Sankara's impersonal nirguna Brahman concept (Dalal [2010] 2014, pp. 334-35; Boyd 2000, pp. 19-20). S. Radhakrishnan states that, "Shankara and Ramanuja were both great exponents of Vedanta, examined the same texts, and based their ideas on the same assumptions, yet reached different conclusions" (Dalal [2010] 2014, pp. 457-58). While Sankara emphasized God's existence as the absolute reality over against the relatively real status of human beings and the world, Ramanuja concluded that a personal relationship between God and human beings is possible. John perceives God as the Supreme or Ultimate Reality; but, the evangelist neither portrays God as nirguna nor present human beings as totally dependent to God (McPolin 2020, pp. 25-26). John teaches that human personality can either accept or reject God; but, a union is possible between God and human beings through the initiative of knowing God, doing his work, and devoting oneself in faith (Dalal [2010] 2014, pp. 457-58). Though John sustains certain commonalities with the non-dualistic and the qualified non-dualistic trends of Sankara and Ramanuja, the narrator expounds his thought-world within a dualistic framework.

\section{Dualism in John and in the Indian Context}

The Fourth Gospel is well-known for its dualistic framework. In John, this trend begins with the pair of light and darkness being placed at the outset (1:5; Van der Watt 2007a, pp. 30-32; Anderson 2011b, pp. 36-38). Other dualistic pairs in John include: above and below (8:23), spirit and flesh (3:6), life (eternal) and death (3:36), belief and disbelief 
(3:18), truth and falsehood (8:44-47), heaven and earth (3:31), God and Satan (13:27), and Israel and "the Jews" (1:19 and 47; Vande Kappelle 2014, p. 84). As in Judaism, John develops a modified dualism that affirms God's sovereign rule as an overcomer of evil (see Vande Kappelle 2014, p. 85; Orton 1999, p. 7). Scholars, including Richard Bauckham, observe similarities between Johannine dualism and that of the OT (Gen 1:3-5; Isa 9:2; 42:6-7; 60:1-3), Qumran (1QS 3.3-4.26), and Gnostic writings (Bauckham 2015, pp. 117-18). John's trend of dualism has many parallels in the Indian context.

Among the Indian religions, Zoroastrianism reflects a complete separation of good and evil at the cosmic and the moral levels. Cosmic dualism refers to the ongoing battle between Good (Ahura Mazda) and Evil (Andra Mainyu) within the universe. Moral dualism refers to the opposition of good and evil in the mind of humankind. In Zoroastrianism, good and evil are considered equal and opposite realities. ${ }^{22}$ In that sense, the propositions of three Indian religious/philosophical schools are noteworthy: Zoroastrianism follows an unqualified dualism; Sankara's Advaita philosophy advocates an unqualified non-dualism; Ramanuja proposes a qualified non-dualism. John maintains a dualistic framework as in Zoroastrianism; but, he distances himself from Zoroastrianism through his creativity of setting a qualified dualism.

John interprets God as the absolute reality and suggests a union between God and the human beings, as it is in Advaita; but, he considers neither a non-dualistic existence of God nor that God is nirguna or without attributes. ${ }^{23}$ John proposes a personal relationship between God and human beings and suggests a Bhakti Marga, as in Ramanuja; but, John goes beyond the qualified non-dualism of Vishishtadvaita. ${ }^{24}$ In his propositions, John is closer in many ways to the principles of Madhava, a 12th century CE interpreter of Vedanta, who suggested a Dvaita philosophy (Dalal [2010] 2014, pp. 227-28). Madhava considered the supremacy of Brahman and the separate existence of human beings/the world. His dualism was not true dualism in the sense of two equal powers (Dalal [2010] 2014, p. 128). Here we see a connection between the qualified dualism of John (1:5) with the qualified dual existence suggested by Madhava. This comparison of various religious and philosophical traditions helps us to understand John's accommodation of ideas and his distinctive spiritual orientation and emphasis in relation to the Indian thought-world.

\section{Other Johannine Bridges with the Indian Realities}

Alongside the above mentioned observations, some of the following aspects also need to be considered: first, as the Johannine community was treated as a minority sect and were expelled from the Synagogue (9:22, 34; 16:2), Indian Christian communities suffer discrimination and rigorous persecution due to their minority status (Thomaskutty 2016, pp. 9-10; Martyn 2003); second, in Roman Palestine, Jesus worked among the masses, especially those who were poor, marginalized, and ostracized (4:1-26; 5:1-18; 9:1-41). In India, the church, in her mission, focuses on the poor sections of the society (Thomaskutty 2016, pp. 11-12); third, as John portrayed women with respect and on par with men characters $(2: 1-11 ; 4: 1-42 ; 12: 1-8 ; 20: 1-18)$, the Indian churches have adopted the method of a hermeneutics of suspicion so as to make the voice of women heard in the church and in the society (Thomaskutty 2016, pp. 12-13); fourth, as dialogue is the preferable literary genre within John (Thomaskutty 2015, pp. 1-20), Indian Christians are dialogical and interactional in the public arena (Thomaskutty 2016, pp. 16-17); fifth, as in the case of the Johannine community situation, the Dalit communities in India, the Minjung in Korea, and other poor sections across Asia endure economic deprivation, social vulnerability, and religious dehumanization (Basker 2016, pp. 124-43; Thomaskutty 2016, p. 20); sixth, as Mary Magdalene exemplified her devotion through superabundant generosity (12:1-8), the Indian communities are benevolent in hospitality and care even toward strangers; seventh, as the Johannine Jesus expresses mission concerns both at the public level (1:19-12:50) and at the private sector (13:1-17:26), Indian communities can be approached both in their private and public sectors. These aspects of the Fourth Gospel can bridge the gulf between the Sitz-im-Leben of the Johannine community and the Siz-im-Leben of the Indians. 
The Gospel of John has genuine global significance. It speaks equally to pluralistic Indians, communist and Confucian Chinese, Muslim Bangladeshis and Pakistanis, Buddhist Burmese and Cambodians, Shamanistic Koreans and Philippines, Taoistic Japanese, and others in Asian contexts. Its messages of peace, love, faith-centered life, holistic salvation, and the mission of God have the potential to liberate and transform the societies across the Asian continent. In Asia, a missional hermeneutic that crosses the traditional boundaries of interpretation and builds dialogical bridges between the world of John and that of our own time may be very effective. Such boundary-crossing and bridge-building will enable the Indian readers of John to direct their communities to a "third space" for dialogue. This should be paradigmatic for the Indians as a whole.

\section{Conclusions}

In sum, the Fourth Gospel has a large number of terminological and conceptual parallels with the Indian socio-religious and philosophical traditions. These qualities of the Gospel of John fit well within the spectrum of Indian socio-political, religious, and spiritual realities. The universalistic linguistic and literary style, the appearance of characters as representative figures, the conceptual linkage between the Indian religions and philosophical ideologies, and the open-ended outlook of the signs fit well within the contextual aspects of Indian culture. John's nature as a "riddle" is obvious when it appears mystical, and at the same time dualistic, advaitic and dvaitic, Indianizing and indigenizing, local and universal, and divine and human. Indian and Asian religious and philosophical thought-worlds such as Hinduism, Buddhism, Jainism, Sikhism, Zoroastrianism, and others have Johannine parallels. In the Gospel of John, we see that the narrator echoes a number of Indian concepts and ideologies, and at the same time he distances himself from them all in order to recreate everything in a "third space." Thus, the cross-cultural nature of the Fourth Gospel can be well-aligned within the pluralistic context of India. By crossing the traditional boundaries, creating ideological constellations, and building dialogical relationships, the narrator of the story aims to direct the Indian minds toward a "third space" (Thomaskutty 2020, p. 151). The Johannine Jesus appears as a friend of the socially vulnerable, religiously expelled/persecuted, and spiritually thirsty such as the Dalits, Tribals, Adivasis, and other sections of society.

Funding: This research received no external funding.

Institutional Review Board Statement: Not Applicable.

Informed Consent Statement: Not Applicable.

Data Availability Statement: Not Applicable.

Conflicts of Interest: The author declares no conflict of interest.

\section{Notes}

1 Chandogya Upanishad belongs to Tandya School under Kauthuma Samhita of the Samaveda. Out of the ten chapters of the Chandogya Brahmana, chapters third to tenth are considered as the Chandogya Upanishad." For more details, see http:/ / vedicheritage.gov.in/upanishads/chandogyopanishad/, accessed on 11 April 2021.

2 Though there are similarities between the Hindu understanding of avatāra and Christian understanding of incarnation, Keshub Chandra Sen and Upadhyaya were against the trend of considering both as same. Boyd says, "There is only one Incarnation, that is Christ, for he is unique and in him God himself, Parabrahman than whom there can be none higher, becomes incarnate" (see Boyd 2000, p. 81).

3 See https://www.britannica.com/topic/Hinduism/Karma-samsara-and-moksha\#ref50477, accessed on 30 April 2020.

4 The expressions like to ergon (4:34), ergadzetai and ergadzomai (5:17), ta erga and ergadzesthai (9:3-4) are used to emphasize the aspect of work.

5 See http:/ / aguidetohinduism.blogspot.com/2012/01/three-paths-of-liberation-8.html, accessed on 30 May 2020. Ramanuja was an Indian philosopher and a teacher of salvation. He taught that salvation is not attained by one's works, but comes through bhakti-attachment and devotion in love and faith and that salvation is a gift by the saving grace of God. Through both the 
Gospel of John and in Ramanuja, a better understanding of the dwelling of God in human beings is manifested (See Philip 2018; Appasamy 1928, p. 13).

6 For more details about the Johannine discipleship, see (Thomaskutty 2016, pp. 5-21).

7 Peripatetic School is "the school founded by Aristotle in Athens in 336 BCE, supposedly named after the peripatos or covered walk in the garden of the Lyceum, where he lectured. Apart from Aristotle, its important members were Theophrastus, Eudemus of Rhodes, and Strato of Lampsacus." In the Fourth Gospel, Jesus adopts a Peripatetic style as a walking teacher as his disciples follow him. See https: / www.oxfordreference.com/view/10.1093/oi/authority.20110803100317855, accessed on 2 May 2020.

8 See https://www.britannica.com/topic/Guru-Sikhism, accessed on 1 May 2020.

9 Above all, the resurrection of Jesus from the dead reveals his glory to the world (20:1-29).

10 See more details regarding signs in John's Gospel, in Anderson (2014, pp. 145-46).

11 See (Burge 1992, pp. 354-56). For the Cognitive-Critical origin of John's I-Am sayings, see (Anderson 2011a, pp. 139-206).

12 B. R. Nanda, “Mahatma Gandhi,” https:/ / www.britannica.com/biography/Mahatma-Gandhi, accessed on 3 April 2020.

13 See https://www.nytimes.com/2018/11/14/obituaries/pandita-ramabai-overlooked.html, accessed on 3 April 2020.

14 See https://www.nobelprize.org/prizes/peace/1979/teresa/biographical/, accessed on 3 April 2020.

15 More details about the characterization of Thomas, see (Thompson 2015, p. 242; ); for more details about these characters, see (Gench 2007).

16 See https://www.britannica.com/plant/Bo-tree, accessed on 3 April 2020.

17 This story is described in the Matangi Sutra of Buddhist Sources. This encounter gave birth to Shurangana Sutra. Chandalabhikshuki is a well acclaimed Malayalam poem written by Kumaranasan (1873-1924), a famous poet from Kerala. This is a poetic representation of a well-encounter story from Buddhism. The poet sets the time around 2500 years back. This incident happens in North India, in a village near the place called Sravasti.

18 Basker sees the ideas of mystical love, unity, oneness, life in fullness, and others have close affinity to Hindu spirituality. Basker says, "Several Christian converts have found similarities between Hinduism and the Gospel of John and have proceeded to interpret this Gospel from an Indian-Hindu perspective." See (Basker 2016, p. xvii; McPolin 2020, pp. 30-31).

The Mahavakyas of Upanishads like Aham Brahma-asmi ("I am Brahman"), Tat tvam asi ("You are That"), Ayamatma Brahma ("the Atma is Brahman"), and Brahma satyam, jagan mithya ("Brahman is real, the world is unreal") make it affirm the oneness aspect of Hinduism. See (Dalal [2010] 2014, p. 234).

20 Lisa Jo Rudy, “What is Mysticism? Definition and Examples,” https:/ /www.learnreligions.com/mysticism-definition-4768937, accessed on 3 May 2020.

21 The Fourth Gospel deals with the indwelling of God in human beings at various points. We find it in the concept of Logos in the prologue to the Gospel (1:1-18), then in the Farewell Discourses (chaps. 13-17) where we have the Paraclete passages in which Jesus speaks of God, Jesus himself and the Holy Spirit coming and indwelling in the believers of Jesus (14:15-24). The metaphor of the vine and the branches (15:1-17) is also very significant in this respect. The high priestly prayer of Jesus (chap. 17) also throws a lot of light into the divine indwelling in human beings who believe in Jesus. See (Philip 2018.) See https:/ / www.bbc.co.uk/religion/religions/zoroastrian/beliefs/dualism.shtml, accessed on 5 May 2020.

23 In Sankara's Advaita philosophy, God is considered as the single reality without a second and for him God is nirguna Brahman. Ramanuja proposes a qualified non-dualism that is distinct from the qualified dualism of John.

\section{References}

Anderson, Paul N. 2011a. The Origin and Development of the Johannine Egō Eimi Sayings in Cognitive-Critical Perspective. Journal for the Study of the Historical Jesus 9: 139-206. [CrossRef]

Anderson, Paul N. 2011b. The Riddles of the Fourth Gospel: An Introduction to John. Minneapolis: Fortress Press.

Anderson, Paul N. 2013. Following Jesus: The Heart of Faith and Practice. Newberg: Barclay Press.

Anderson, Paul N. 2014. From Crisis to Christ: A Contextual Introduction to the New Testament. Nashville: Abingdon Press, pp. $144-45$.

Appasamy, Ayadurai Jesudasan. 1928. Christianity as Bhakti Marga: A Study of the Johannine Doctrine of Love. Madras: CLS.

Appasamy, Ayadurai Jesudasan. 1958. Sundar Singh: A Biography. London: Lutterworth Press.

Ashton, John. 1993. Understanding the Fourth Gospel. Oxford: OUP. First published 1991.

Ball, David Mark. 1996. I Am in John's Gospel: Literary Function, Background, and Theological Implications. JSNTSS 124. Sheffield: Sheffield Academic Press.

Barrett, Charles Kingsley. 1978. The Gospel According to St. John: An Introduction with Commentary and Notes on the Greek Text. London: SPCK.

Basker, Gregory Thomas. 2016. Interpreting Biblical Texts: John and His Tamil Readers. New Delhi: ISPCK.

Bauckham, Richard. 2015. Gospel of Glory: Major Themes in Johannine Theology. Grand Rapids: Baker Academic.

Beasley-Murray, George Raymond. 1999. John. Word Biblical Commentary 36. Nashville: Thomas Nelson Publishers.

Bennema, Cornelis. 2009. Encountering Jesus: Character Studies in the Gospel of John. Bangalore: Primalogue. 
Blackburn, Bruce L. 1992. Miracles and Miracle Stories. In Dictionary of Jesus and the Gospels. Edited by Joel B. Green, Scot McKnight and I. Howard Marshall. Downers Grove: Inter-Varsity Press.

Blomberg, Craig L. 2001. The Historical Reliability of John's Gospel: Issues and Commentary. Leicester: Apollos.

Boyd, Robert. 2000. An Introduction to Indian Christian Theology. Delhi: ISPCK.

Brant, Jo-Ann A. 2011. John. Paideia Commentaries on the New Testament. Grand Rapids: Baker Academic.

Brown, Raymond Edward. 1979. The Community of the Beloved Disciple. New York: Paulist.

Burge, Gary M. 1992. I Am' Sayings. In Dictionary of Jesus and the Gospels. Downers Grove: InterVarsity Press, pp. $354-56$.

Chacko, B. 2019. Samaritan Woman, Chandalabhikshuki and a Third Space of Hermeneutics: Reading the 'Well-Encounter' in John 4 from an Intercultural Perspective. An Academic Paper. Bengaluru: SAIACS, pp. 1-12.

Chandrankunnel, Mathew. 2021. Logos and Dharma: A Spiritual-Hermeneutical Analysis of the Fourth Gospel to Proclaim Jesus as Sanatana Sat Guru. In Wider Contextualized Biblical Spirituality. Edited by Johnson Thomaskutty and Mathew Chandrankunnel. New Delhi: Christian World Imprints, pp. 171-92.

Chatman, Seymour. 1978. Story and Discourse: Narrative Structure in Fiction and Film. Ithaca: Cornell University Press.

Coloe, Mary L. 2013. The Mother of Jesus: A Woman Possessed. In Character Studies in the Fourth Gospel. Edited by Steven A. Hunt, D. Francois Tolmie and Ruben Zimmerman. Grand Rapids: Eerdmans.

Dalal, Roshen. 2014. Hinduism: An Alphabetical Guide. Gurgaon: Penguin Books. First published 2010.

Gaffney, James. 1965. Believing and Knowing in the Fourth Gospel. Theological Studies 26: 215-41. [CrossRef]

Gench, Frances Taylor. 2004. Back to the Well: Women's Encounters with Jesus in the Gospels. Louisville: Westminster John Knox Press.

Gench, Frances Taylor. 2007. Encounters with Jesus: Studies in the Gospel of John. Louisville: Westminster John Knox Press.

Guthrie, Donald. 1990. New Testament Introduction, rev. ed. Downers Grove: InterVarsity Press, pp. 272-73.

Kanagaraj, J. J. 2005. The Gospel of John: A Commentary. Secunderabad: OM Books.

Kohli, Surindar Singh. 1993. The Sikh and Sikhism. New Delhi: Atlantic Publishers.

Lee, Dorothy A. 1994. The Symbolic Narratives of the Fourth Gospel. JSNTSS 95. Sheffield: Aheffield Academic Press.

Martyn, J. Louis. 1979. History and Theology in the Fourth Gospel, 2nd ed. Nashville: Abingdon.

Martyn, J. Louis. 2003. History and Theology in the Fourth Gospel, 3rd ed. Louisville: Westminster John Knox.

McPolin, James. 2020. Johannine Mysticism. pp. 26-27. Available online: https://www.theway.org.uk/back/18McPolin.pdf (accessed on 3 May 2020).

Moloney, Francis J. 1998. The Gospel of John. Sacra Pagina 4. Collegeville: The Liturgical Press. First published 1989.

Narasu, Pokala Lakshmi. 2009. The Essence of Buddhism. New Delhi: Gautam Printers.

Orton, David E. 1999. The Composition of John's Gospel: Selected Studies from Novum Testamentum. Leiden and Boston: Brill.

Owens, M. 2008. “OM". In Encyclopaedia of Hinduism. Edited by Denise Cush, Catherine Robinson and Michael York. London and New York: Routledge.

Philip, A. 2018. History and Theology of the Gospel According to St. John. Tiruvalla: CSS.

Rambachan, Anantanand. 2005. To Recognize and Love God in All: An Introduction to Hinduism. In Five Voices, Five Faiths: An Interfaith Primer. Cambridge: Cowley, p. 7.

Ringe, Sharon H. 1999. Wisdom's Friends: Community and Christology in the Fourth Gospel. Louisville: Westminster John Knox Press.

Roy, Raja Ram Mohan. 2008. The Precepts of Jesus: The Guide to Peace and Happiness. San Francisco: BiblioLife.

Schnackenburg, Rudolf. 1982. The Gospel According to St. John. New York: Herder and Herder, vol. 3.

Thomaskutty, Johnson, ed. 2015. Dialogue in the Book of Signs: A Polyvalent Analysis of John 1:19-12:50. BINS 136. Leiden and Boston: E. J. Brill.

Thomaskutty, Johnson, ed. 2016. Reading John's Gospel in the Nepali Context. Journal of Asian Evangelical Theology 20: 5-21.

Thomaskutty, Johnson, ed. 2017a. Biblical Interpretation in the Global-Indian Context. Fuller Magazine. Issue 8: 64-68.

Thomaskutty, Johnson, ed. 2017b. Reading John's Gospel in the Bangladeshi Context. Journal of Asian Evangelical Theology $21:$ 53-72.

Thomaskutty, Johnson, ed. 2018. Saint Thomas the Apostle: New Testament, Apocrypha, and Historical Traditions. T \& T Clark Jewish and Christian Texts Series 25; London: Bloomsbury T \& T Clark.

Thomaskutty, Johnson. 2019. Faith and Theology in the Johannine Community and in the Reformation: A Paradigm in the Indian Context. In Faith and Theology: Basic Insights of the Reformation in Ecumenical Debate. Edited by Wolfram Kinzig and Julia Winnebeck. Leipzig: Evangelische Verlagsanstalt, pp. 75-96.

Thomaskutty, J., ed. 2020. The Gospel of John: A Universalistic Reading. Biblical Hermeneutics Rediscovered 25. New Delhi: Christian World Imprints.

Thomaskutty, J., ed. 2021a. An Asian Introduction to the New Testament. Minneapolis: Fortress Press.

Thomaskutty, Johnson. 2021b. Johannine Spirituality in the Indian/Asian Contexts. In Wider Contextualized Biblical Spirituality. Edited by Johnson Thomaskutty and Mathew Chandrankunnel. New Delhi: Christian World Imprints, pp. 155-70.

Thomaskutty, Johnson, ed. 2021c. Reading the Fourth Gospel in the COVID-19 pandemic Context. HTS Theologiese Studies/Theological Studies 77: a6355. [CrossRef]

Thompson, Marianne Meye. 2001. The God of the Gospel of John. Grand Rapids: Eerdmans.

Thompson, Marianne Meye. 2015. John: A Commentary. NTL. Louisville: Westminster John Knox.

Tovey, Derek. 2007. Jesus: Story of God; John's Story of Jesus. Adelaide: ATF Press.

Van der Watt, Jan Gabriël. 2007a. An Introduction to the Johannine Gospel and Letters. London: T\&T Clark. 
Van der Watt, Jan Gabriël. 2007b. I Am the Bread of Life: Imagery in John 6:32-51. Acta Theologica 27: 186-204. [CrossRef] Vande Kappelle, Robert P. 2014. Truth Revealed: The Message of the Gospel of John Then and Now. Eugene: Wipf \& Stock.

Vyasa, Krishna-Dwaipayana. 2013. The Mahabharata of Krishna-Dwaipayana Vyasa Book 7 Drona Parva. London: Bottom of the Hill Publishing.

Wilkins, Michael J. 1992. Disciples. In Dictionary of Jesus and the Gospels. Downers Grove: Inter-Varsity Press. 